Open Access

Res. Agric. Livest. Fish.

Research Article

Vol. 2, No. 1, April 2015: 43-51

\title{
SHOOT REGENERATION AND ROOT INDUCTION IN BRINJAL BY GROWTH REGULATORS
}

\section{Md. Abdul Alim ${ }^{1}$, Bhabendra Kumar Biswas ${ }^{2}$, Md. Hasanuzzaman ${ }^{2}$, Pronay Bala ${ }^{3^{*}}$ and Santanu Roy ${ }^{4}$}

${ }^{1}$ Assistant Production Manager, ACl (Seed) Ltd.; ${ }^{2}$ Professor, Department of Genetics and Plant Breeding, Hajee Mohammad Danesh Science and Technology University (HSTU), Dinajpur, Bangladesh; ${ }^{3} \mathrm{PhD}$ Fellow, Department of Crop Physiology \& Ecology, HSTU, Dinajpur; ${ }^{4}$ Program officer, Natural Resources Management Project, Caritas Fisheries Program, Mirpur, Dkaka, Bangladesh

*Corresponding author: Pronay Bala; E-mail: kbdpronay@yahoo.com

\section{ARTICLE INFO ABSTRACT}

\section{Received}

02.03.2015

Accepted

12.04.2015

Online

19.04.2015

Key words

Regeneration Induction

Root

Brinjal

Growth regulators
The experiment was carried out to study the effect of genotypes and growth regulators on root induction and shoot regeneration of brinjal (Solanum melongena) genotypes. Leaf segments of three varieties of Solanum were cultured on MS medium with different concentrations and combinations of plant growth regulators. Among the tested genotypes, Protab showed highest percentage of shoot regeneration $(65.67 \%)$. Early and maximum rate of regeneration was found in $\mathrm{MS}+1 \mathrm{mg} / \mathrm{L} \mathrm{NAA}$ (naphthalene acetic acid) $+0.1 \mathrm{mg} /$ LBAP (6-benzylamino purine) for all the genotypes. The highest number of roots per shoot was counted in Protab $(73.33 \%)$ on $1 / 2 \mathrm{MS}+2 \mathrm{mg} / \mathrm{L}$ IBA (indole butyric acid) $+0.4 \mathrm{mg} / \mathrm{L}$ BAP. Based on the overall performance, the variety Protab appeared as the best for shoot and root formation and ultimately successful regeneration of plants.

To cite this article: MA Alim, BK Biswas, M Hasanuzzaman, P Bala and S Roy. 2015. Shoot regeneration and root induction in brinjal by growth regulators. Res. Agric. Livest. Fish. 2 (1): 43-51.

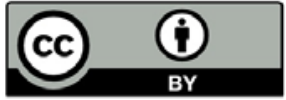




\section{INTRODUCTION}

Brinjal (Solanum melongena L.), belongs to the family Solanaceae, is one of the most popular, palatable and nutritious vegetable crop in Bangladesh. It is thought to be originated in Indian sub-continent with the secondary centre of origin in China (Zeven and Zhukovsky, 1975). The area of brinjal cultivation in Bangladesh is 45.57 thousand hectare and production is 3.40 lac metric tons (BBS, 2011). Brinjal is an economically important vegetable comprising an imperative supply of dietary protein, carbohydrate, vitamins and minerals particularly for the vegetarian population of developing countries. It has higher calorie, iron, phosphorus and riboflavin than tomato (Ray et al., 2011). However, the quality of brinjal varies with shape, size and colour of fruits (Bose and Som, 1986). Brinjal can be cultivated as a year round crop but the productivity and quality of this crop suffer due to its susceptibility to a number of diseases and insect pests (Sadilova et al., 2006).

In popular medicine, eggplant is indicated for the treatment of several diseases, including diabetes, arthritis, asthma and bronchitis and reducing blood and liver cholesterol rates in humans (Jorge et al., 1998). Brinjal is cultivated throughout the entire tropics and sub-tropics. Plant regeneration is somehow dependent on the type of explants such as cotyledon (Bardhan et al., 2012, Mir et al., 2011). The type and concentration of growth regulators and varieties can cause significant differences in morphogenetic responses of brinjal (Magioli and Mansur, 2005). The present study was undertaken to develop a suitable regeneration protocol for the tested three brinjal genotypes grown in Bangladesh.

\section{MATERIALS AND METHODS}

The experiment was carried out during the period from September, 2011 to January, 2012 in the Biotechnology Laboratory at the Department of Biotechnology of Hajee Mohammad Danesh Science and Technology University, Dinajpur. The varieties of Brinjal used in the present investigation namely-Protab, Green Ball and Ghemma Begun (Local) were collected from A.R. Mallik Seeds Co. Metal Agro Ltd. and locally from Dinajpur.

The surface sterilization of seeds was carried out under a Laminar Air Flow Cabinet. The floated seeds were discarded and others were rinsed in $70 \%$ ethyl alcohol for one minute, and then thoroughly washed with sterilized water. The alcohol treated seeds were immersed into $0.1 \% \mathrm{HgCl}_{2}$ solution for 8-10 minutes, few drops Tween-20 per $100 \mathrm{ml}$ were also added at that time. The seeds were then washed 5-6 times with sterilized distilled water. Sterilized seeds were placed into seed germination medium in vials. Six seeds were placed in each vial. The culture was then incubated in dark till the germination of seeds. These vials were then transferred to 16 hours light for normal seedling growth. Twenty one days old seedlings were used as source of contamination free explants. The seedlings raised in axenic culture were used as the source of different kinds of explants. The leaf segments were used as explants. Leaf segment from each germinated seedling were cut into small pieces using sterilized scalpel under a Laminar Air Flow cabinet. Four pieces of leaf segments were arranged on each vials and gently pressed into the surface of the sterilized culture medium with various combinations and concentrations of growth regulators viz., $\mathrm{T}_{1}=\mathrm{MS}$ medium containing with 1 $\mathrm{mg} / \mathrm{L}$ NAA (Napthaline acetic acid) $+0.1 \mathrm{mg} / \mathrm{L}$ BAP (6-benzylamino purine) $\mathrm{T}_{2}=\mathrm{MS}$ medium containing with $1.5 \mathrm{mg} / \mathrm{L} \mathrm{NAA}+0.5 \mathrm{mg} / \mathrm{l} \mathrm{BAP}, \mathrm{T}_{3}=\mathrm{MS}$ medium containing with $1.5 \mathrm{mg} / \mathrm{L} \mathrm{NAA}+1 \mathrm{mg} / \mathrm{l} \mathrm{BAP}, \mathrm{T}_{4}=\mathrm{MS}$ medium containing with $1 \mathrm{mg} / \mathrm{L} \mathrm{NAA}+1.5 \mathrm{mg} / \mathrm{l} \mathrm{BAP}$ and $T_{5}=\mathrm{MS}$ medium containing with $0.5 \mathrm{mg} / \mathrm{L} \mathrm{NAA}+2 \mathrm{mg} / \mathrm{L}$ BAP. MS media with different concentrations and combinations of BAP and NAA (e.g., $T_{1}=1 / 2$ MS medium containing $2 \mathrm{mg} / \mathrm{LIBA}+0.4 \mathrm{mg} / \mathrm{L}$ BAP, $\mathrm{T}_{2}=1 / 2 \mathrm{MS}$ medium containing with $1 \mathrm{mg} / \mathrm{L}$ IBA $+0.3 \mathrm{mg} / \mathrm{l} \mathrm{BAP}$ and $\mathrm{T}_{3}$ $=1 / 2 \mathrm{MS}$ medium containing with $0.5 \mathrm{mg} / \mathrm{L} \mathrm{IBA}+0.2 \mathrm{mg} / \mathrm{L}$ BAP) were used for root formation. The subculture vials were again incubated at $25 \pm 2^{\circ} \mathrm{C}$ with moderate light intensity. All cultures were examined regularly and the vials showing symptoms of contamination were discarded.

The plantlets with sufficient root system were separated from the vials. Agar was gently washed out with running tap water from root. The plantlets transplanted to small pots containing garden soil, sands and cowdung at the ratio of 1: $2: 1$. Immediately after transplantation, the plants along with pots were covered with moist polythene bag to prevent desiccation. To reduce sudden shock, the pots were kept in the controlled environment in a growth room. The interior of the polythene bags were sprayed with water at every 24 hours to maintain high humidity around the plantlets. At the time plantlets were also nourished with Hoagland's solution. 
After 2-3 days, the polythene bags were gradually perforated to expose the plants to natural environment. The polythene bags were completely removed after 7-10 days. The plantlets at this stage were placed in natural environment for 3-10 hours daily.

The established plants were calculated based on the number of plantlets placed in the pot and number of plants finally established or survived.

$$
\text { Percent plant establishment }=\frac{\text { Number of established plantlets }}{\text { Total number of plantlets }} \times 100
$$

\section{Statistical analysis of data}

The experiments were arranged in Completely Randomized Design (CRD). The analysis of variance for different characters was analyzed using MSTAT-C and means were compared by the Duncan's Multiple Range Test (DMRT).

\section{RESULTS AND DISCUSSION}

The main effect of genotypes, phyto-hormones and combination of these two in brinjal was found to be significant on shoot and root regeneration (Table 1-6).

The present study described development of a rapid and efficient plantlet regeneration protocol using leaf segment obtained from in vitro grown seedling. The type and concentration of a growth regulator was found to have significant impact on morphogenetic responses. The results of shoot regeneration from various brinjal explants at different growth regulators concentration and combinations are given in Table1-3. All three explants initiated callus and formed shoots on all five combinations of growth regulators tested. It was observed that induction and regeneration was quite permissive over a wide range of plant growth regulators.

Table 1. Main effects of genotypes on shoot regeneration

\begin{tabular}{|lccc|}
\hline Genotypes & $\begin{array}{l}\text { Total no. of calli with } \\
\text { shoot }\end{array}$ & $\begin{array}{l}\text { Shoot regeneration } \\
\text { (\%) }\end{array}$ & $\begin{array}{c}\text { Days required for shoot } \\
\text { initiation }\end{array}$ \\
\hline Protab & $13.13 \mathrm{a}$ & $65.67 \mathrm{a}$ & $40.27 \mathrm{c}$ \\
Green Ball & $11.27 \mathrm{c}$ & $56.33 \mathrm{~b}$ & $47.93 \mathrm{a}$ \\
Ghemma Begun (Local) & $10.47 \mathrm{~b}$ & $52.33 \mathrm{c}$ & $48.33 \mathrm{a}$ \\
LSD & 0.6761 & 3.381 & 1.089 \\
CV (\%) & $7.80 \%$ & $7.80 \%$ & $3.05 \%$ \\
\hline
\end{tabular}

Table 2. Main effects of treatments on shoot regeneration

\begin{tabular}{|llll|}
\hline Treatment & $\begin{array}{l}\text { Total no. of calli with } \\
\text { shoot }\end{array}$ & $\begin{array}{l}\text { Shoot regeneration } \\
\mathbf{( \% )}\end{array}$ & $\begin{array}{l}\text { Days required for } \\
\text { shoot initiation }\end{array}$ \\
\hline $\mathrm{T}_{1}$ & $12.27 \mathrm{a}$ & $65.83 \mathrm{a}$ & $45.00 \mathrm{c}$ \\
$\mathrm{T}_{2}$ & $12.00 \mathrm{ab}$ & $60.00 \mathrm{ab}$ & $46.78 \mathrm{c}$ \\
$\mathrm{T}_{3}$ & $12.00 \mathrm{ab}$ & $60.00 \mathrm{ab}$ & $48.22 \mathrm{~b}$ \\
$\mathrm{~T}_{4}$ & $11.33 \mathrm{~b}$ & $56.67 \mathrm{~b}$ & $49.33 \mathrm{~b}$ \\
$\mathrm{~T}_{5}$ & $10.22 \mathrm{c}$ & $51.11 \mathrm{c}$ & $50.89 \mathrm{a}$ \\
$\mathrm{LSD}$ & 0.8729 & 4.365 & 1.406 \\
$\mathrm{CV}(\%)$ & $7.80 \%$ & $7.80 \%$ & $3.05 \%$ \\
\hline
\end{tabular}

$\mathrm{T}_{1}=\mathrm{MS}$ medium containing with $1 \mathrm{mg} / \mathrm{NAA}+0.1 \mathrm{mg} / \mathrm{BAP} ; \mathrm{T}_{2}=\mathrm{MS}$ medium containing with $1.5 \mathrm{mg} / \mathrm{l} \mathrm{NAA}+0.5 \mathrm{mg} / \mathrm{l} \mathrm{BAP}$ $\mathrm{T}_{3}=\mathrm{MS}$ medium containing with $1.5 \mathrm{mg} / \mathrm{NAA}+1 \mathrm{mg} / \mathrm{BAP} ; \mathrm{T}_{4}=\mathrm{MS}$ medium containing with $1 \mathrm{mg} / \mathrm{l} \mathrm{NAA}+1.5 \mathrm{mg} / \mathrm{BAP}$ $\mathrm{T}_{5}=\mathrm{MS}$ medium containing with $0.5 \mathrm{mg} / \mathrm{l} \mathrm{NAA}+2 \mathrm{mg} / \mathrm{l} \mathrm{BAP}$ 
Table 3. Combined effect of variety and hormone concentrations on shoot regeneration

\begin{tabular}{|c|c|c|c|c|}
\hline \multicolumn{2}{|c|}{ Hormone $\times$ genotype } & \multirow{2}{*}{$\begin{array}{l}\text { Total no. of calli } \\
\text { with shoot } \\
14.33 \mathrm{a}\end{array}$} & \multirow{2}{*}{$\begin{array}{l}\begin{array}{l}\% \text { Shoot } \\
\text { regeneration }\end{array} \\
71.67 \mathrm{a}\end{array}$} & \multirow{2}{*}{$\begin{array}{l}\text { Days required for } \\
\text { shoot initiation } \\
43.33 \mathrm{~g}\end{array}$} \\
\hline $\mathrm{T}_{1}$ & Protab & & & \\
\hline & Green Ball & $12.00 \mathrm{c}-\mathrm{f}$ & $60.00 \mathrm{c}-\mathrm{f}$ & $45.67 \mathrm{e}-\mathrm{g}$ \\
\hline & $\begin{array}{l}\text { Ghemma Begun } \\
\text { (Local) }\end{array}$ & $11.33 d-f$ & $56.67 d-f$ & $47.00 \mathrm{c}-\mathrm{f}$ \\
\hline \multirow[t]{3}{*}{$\mathrm{T}_{2}$} & Protab & $14.00 \mathrm{ab}$ & $70.00 \mathrm{ab}$ & $45.67 \mathrm{e}-\mathrm{g}$ \\
\hline & Green Ball & $11.00 \mathrm{e}-\mathrm{g}$ & $55.00 \mathrm{e}-\mathrm{g}$ & 46.00 ef \\
\hline & $\begin{array}{l}\text { Ghemma Begun } \\
\text { (Local) }\end{array}$ & $11.00 \mathrm{e}-\mathrm{g}$ & $55.00 \mathrm{e}-\mathrm{g}$ & $44.27 \mathrm{fg}$ \\
\hline \multirow[t]{3}{*}{$\mathrm{T}_{3}$} & Protab & $13.00 \mathrm{a}-\mathrm{c}$ & $65.00 \mathrm{a}-\mathrm{c}$ & $46.67 d-f$ \\
\hline & Green Ball & $12.33 \mathrm{c}-\mathrm{e}$ & $58.67 \mathrm{f}$ & $48.67 \mathrm{~b}-\mathrm{d}$ \\
\hline & $\begin{array}{l}\text { Ghemma Begun } \\
\text { (Local) }\end{array}$ & $10.67 \mathrm{f}-\mathrm{h}$ & $53.33 \mathrm{f}-\mathrm{h}$ & $49.33 \mathrm{a}-\mathrm{c}$ \\
\hline \multirow[t]{3}{*}{$\mathrm{T}_{4}$} & Protab & $12.67 \mathrm{~b}-\mathrm{d}$ & $63.33 b-d$ & $48.67 \mathrm{~b}-\mathrm{d}$ \\
\hline & Green Ball & $11.67 \mathrm{c}-\mathrm{f}$ & $58.33 \mathrm{c}-\mathrm{f}$ & $48.00 \mathrm{c}-\mathrm{e}$ \\
\hline & $\begin{array}{l}\text { Ghemma Begun } \\
\text { (Local) }\end{array}$ & $9.667 \mathrm{gh}$ & $48.33 \mathrm{gh}$ & $51.03 \mathrm{a}$ \\
\hline \multirow[t]{3}{*}{$T_{5}$} & Protab & $11.67 \mathrm{c}-\mathrm{f}$ & $58.33 c-f$ & $50.67 \mathrm{ab}$ \\
\hline & Green Ball & $9.333 \mathrm{~h}$ & $46.67 \mathrm{~h}$ & $51.33 \mathrm{a}$ \\
\hline & $\begin{array}{l}\text { Ghemma Begun } \\
\text { (Local) }\end{array}$ & $9.667 \mathrm{gh}$ & $48.33 \mathrm{gh}$ & $50.67 \mathrm{ab}$ \\
\hline LSD & & 1.512 & 7.560 & 2.435 \\
\hline CV (\%) & & $7.80 \%$ & $7.80 \%$ & $3.05 \%$ \\
\hline
\end{tabular}

$\mathrm{T}_{1}=\mathrm{MS}$ medium containing with $1 \mathrm{mg} / \mathrm{NAA}+0.1 \mathrm{mg} / \mathrm{BAP} ; \mathrm{T}_{2}=\mathrm{MS}$ medium containing with $1.5 \mathrm{mg} / \mathrm{l} \mathrm{NAA}+0.5 \mathrm{mg} / \mathrm{BAP}$ $\mathrm{T}_{3}=\mathrm{MS}$ medium containing with $1.5 \mathrm{mg} / \mathrm{l} \mathrm{NAA}+1 \mathrm{mg} / \mathrm{l} \mathrm{BAP} ; \mathrm{T}_{4}=\mathrm{MS}$ medium containing with $1 \mathrm{mg} / \mathrm{l} \mathrm{NAA}+1.5 \mathrm{mg} / \mathrm{l} \mathrm{BAP}$ $\mathrm{T}_{5}=\mathrm{MS}$ medium containing with $0.5 \mathrm{mg} / \mathrm{l} \mathrm{NAA}+2 \mathrm{mg} / \mathrm{l} \mathrm{BAP}$

Table 4. Performance of different genotypes on root induction

\begin{tabular}{|lccc|}
\hline Genotypes & $\begin{array}{c}\text { No. of shoots with } \\
\text { root }\end{array}$ & \% Root induction & $\begin{array}{c}\text { Days required to root } \\
\text { initiation }\end{array}$ \\
\hline Protab & $7.333 \mathrm{a}$ & $73.33 \mathrm{a}$ & $6.00 \mathrm{c}$ \\
Green Ball & $6.222 \mathrm{~b}$ & $62.22 \mathrm{~b}$ & $7.89 \mathrm{~b}$ \\
Ghemma Begun (Local) & $5.000 \mathrm{c}$ & $50.00 \mathrm{c}$ & $8.222 \mathrm{a}$ \\
LSD & 0.467 & 4.669 & 0.4260 \\
CV (\%) & $7.62 \%$ & $7.62 \%$ & $8.07 \%$ \\
\hline
\end{tabular}

Table 5. Performance of growth regulators on different characteristics of root induction

\begin{tabular}{|llll|}
\hline Treatment & $\begin{array}{l}\text { No. of shoots with } \\
\text { root }\end{array}$ & $\begin{array}{l}\text { Root induction } \\
(\%)\end{array}$ & $\begin{array}{l}\text { Days required to } \\
\text { root initiation }\end{array}$ \\
\hline $\mathrm{T}_{1}$ & $6.778 \mathrm{a}$ & $67.78 \mathrm{a}$ & $6.556 \mathrm{~b}$ \\
$\mathrm{~T}_{2}$ & $6.111 \mathrm{~b}$ & $61.11 \mathrm{~b}$ & $7.778 \mathrm{a}$ \\
$\mathrm{T}_{3}$ & $5.667 \mathrm{~b}$ & $56.67 \mathrm{~b}$ & $8.667 \mathrm{a}$ \\
$\mathrm{LSD}$ & 0.4666 & 4.669 & 0.4260 \\
$\mathrm{CV}(\%)$ & $7.62 \%$ & $7.62 \%$ & $8.07 \%$ \\
\hline
\end{tabular}

$\mathrm{T}_{1}=1 / 2 \mathrm{MS}$ medium containing with $2 \mathrm{mg} / \mathrm{IBA}+0.4 \mathrm{mg} / \mathrm{l} \mathrm{BAP}$

$\mathrm{T}_{2}=1 / 2 \mathrm{MS}$ medium containing with $1 \mathrm{mg} / \mathrm{lBA}+0.3 \mathrm{mg} / \mathrm{l} \mathrm{BAP}$

$\mathrm{T}_{3}=1 / 2 \mathrm{MS}$ medium containing with $0.5 \mathrm{mg} / \mathrm{l} \mathrm{IBA}+0.2 \mathrm{mg} / \mathrm{BAP}$ 
Table 6. Effect of growth regulators $x$ variety interaction on different characteristics of root induction

\begin{tabular}{|lllc|}
\hline & Hormone $\times$ genotype & No. of shoots with root & Days required to root initiation \\
\hline $\mathrm{T}_{1}$ & Protab & $7.667 \mathrm{ab}$ & $6.000 \mathrm{e}$ \\
& Green Ball & $7.000 \mathrm{bc}$ & $7.000 \mathrm{~cd}$ \\
& Ghemma Begun (Local) & $5.667 \mathrm{~d}$ & $7.667 \mathrm{de}$ \\
$\mathrm{T}_{2}$ & Protab & $7.332 \mathrm{a}$ & $6.000 \mathrm{~cd}$ \\
& Green Ball & $5.667 \mathrm{~d}$ & $7.667 \mathrm{bc}$ \\
& Ghemma Begun (Local) & $4.667 \mathrm{e}$ & $8.667 \mathrm{bc}$ \\
$\mathrm{T}_{3}$ & Protab & $6.333 \mathrm{~cd}$ & $7.667 \mathrm{bc}$ \\
& Green Ball & $6.000 \mathrm{~d}$ & $7.000 \mathrm{ab}$ \\
& Ghemma Begun (Local) & $4.067 \mathrm{e}$ & $9.333 \mathrm{ef}$ \\
$\mathrm{LSD}$ & & 0.8082 & 0.738 \\
$\mathrm{CV}(\%)$ & & $7.62 \%$ & $8.07 \%$ \\
\hline
\end{tabular}

\section{Shoot regeneration}

\section{Effects of varieties on shoot regeneration}

Genotypes showed significant variations for all the characters of shoot regeneration, percent shoot regeneration and days required for shoot initiations (Table1). From the three genotypes, highest number (13.13) of callus with shoot was found in Protab and lowest in Green Ball (11.27). Protab showed best performances (65.67\%) on percent shoot regeneration. In contrast, Ghemma Begun (Local) showed lowest performance $(52.33 \%)$ on percent shoots regeneration. Days required for shoot initiation was early in Protab (40.27 days) compared to Ghemma Begun (Local) (48.33 days). These results were in agreement with those obtained by Jayasree et al. (2001), Hossain et al. (2007).

\section{Effect of growth regulators on shoot regeneration}

Different concentrations of BAP, NAA showed significant variations for percent shoot regeneration and days required for shoot initiation (Table 2). Among the treatments, $T_{1}(\mathrm{MS}+1 \mathrm{mg} / \mathrm{L} \mathrm{NAA}+0.1 \mathrm{mg} / \mathrm{L} \mathrm{NAA}+0.1$ $\mathrm{mg} / \mathrm{L}$ BAP) showed highest percentage of shoot regeneration (65.83\%) while $\mathrm{T}_{5}(\mathrm{MS}+0.5 \mathrm{mg} / \mathrm{L} \mathrm{NAA}+2 \mathrm{mg} / \mathrm{L}$ BAP) showed lowest (51.11\%). Days required for shoot initiation was minimum (45.00 days) in the $\mathrm{T}_{1}$ (MS+1 $\mathrm{mg} / \mathrm{L} \mathrm{NAA}+0.1 \mathrm{mg} / \mathrm{L}$ BAP) and maximum (50.89 days) in $\mathrm{MS}+0.5 \mathrm{mg} / \mathrm{L} \mathrm{NAA}+2.0 \mathrm{mg} / \mathrm{L}$ BAP (T5). These results were in agreement with those obtained by Rahman et al. (2006). Shivraj and Rao (2011) obtained highest number of shoots on MS medium supplement with $2 \mathrm{mg} / \mathrm{L}$ BAP and 0.5mg/l Kinetin using cotyledonary leaf explant.

\section{Growth regulators $\times$ genotype interaction on shoot regeneration}

Results related to growth regulators $x$ genotype interaction for the characters of shoot regeneration such as total no. of calli with shoot, percent shoot regeneration and days required for shoot initiation in different concentrations of BAP showed significant variations (Table 3). Among the three genotypes, Protab showed highest no. of calli with shoot (14.33), best performance on percent shoot regeneration (71.67\%) in MS +1 $\mathrm{mg} / \mathrm{L} \mathrm{NAA}+0.1 \mathrm{mg} / \mathrm{L}$ BAP $\left(\mathrm{T}_{1}\right)$. In contrast, Ghemma Begun showed lowest number of calli with shoot (9.667) with $\mathrm{MS}+0.5 \mathrm{mg} / \mathrm{L} \mathrm{NAA}+2 \mathrm{mg} / \mathrm{L}$ BAP $\left(\mathrm{T}_{5}\right)$, Green Ball showed lowest percent shoot regeneration (46.67\%) with $\mathrm{MS}+0.5 \mathrm{mg} / \mathrm{L} \mathrm{NAA}+2 \mathrm{mg} / \mathrm{L} \mathrm{BAP}\left(\mathrm{T}_{5}\right)$. Days required for shoot initiation was minimum (43.33 days) on the interactions of $\mathrm{MS}+1 \mathrm{mg} / \mathrm{L} \mathrm{NAA}+0.1 \mathrm{mg} / \mathrm{L}$ BAP $\left(\mathrm{T}_{1}\right)$ with Protab and maximum (51.33 days) on the interactions MS $+0.5 \mathrm{mg} / \mathrm{L} \mathrm{NAA}+2 \mathrm{mg} / \mathrm{L}$ BAP $\left(\mathrm{T}_{5}\right)$ with Green Ball (Table 9$)$. All the genotypes showed satisfactory results with $M S+1 \mathrm{mg} / \mathrm{l} \mathrm{NAA}+0.1 \mathrm{mg} / \mathrm{l}$ BAP $\left(\mathrm{T}_{1}\right)$ treatment. These results were in agreement with those reported by Prakash et al. (2008). Initiation of shoot is shown in Fig. 1. 


\section{Root induction from shoot}

Root induction was found with wide variations at genotypes and different concentrations of growth regulators (Table 4,5 and 6 ).

\section{Effects of genotypes on root induction}

Genotypes showed significant variation in producing root. Protab showed the highest number of shoots with root (7.333), highest percentage of root formation (73.33\%) and minimum days required (6.00). Ghemma Begun (Local) showed lowest number of shoots with root $(5.00)$, lowest percentage $(50.00 \%)$ of root formation and maximum days required (8.222) (Table 4).

\section{Effects of growth regulators on root induction}

Root initiation varied in a wide range due to difference in growth regulators concentrations and combinations (Table 5). Maximum number of shoots with root (6.778) and highest percentage of root formation (67.78\%) were recorded in $1 / 2 \mathrm{MS}+2 \mathrm{mg} / \mathrm{L} \mathrm{IBA}+0.4 \mathrm{mg} / \mathrm{L} \mathrm{BAP}\left(\mathrm{T}_{1}\right)$. Lowest no. of shoots with root (5.667) and lowest percentage of root (56.67\%) formation were found in $T_{3}$ (Table 5). This result was in agreement with those obtained by Das et al. (2002). IBA is widely used for efficient root induction in Brinjal (Zayova et al., 2012; Shivraj and Rao, 2011).

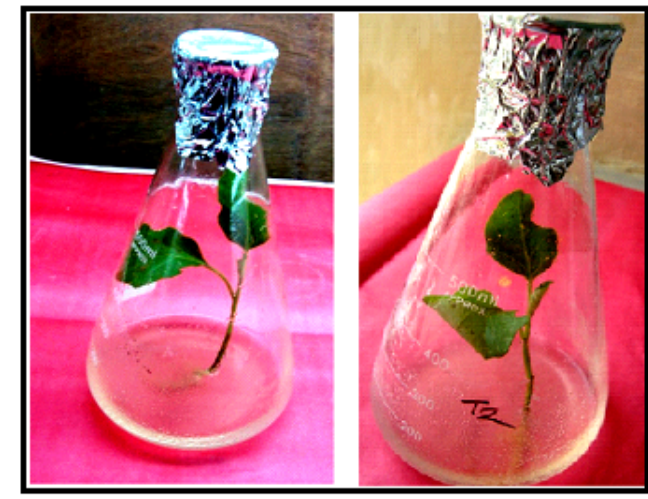

Figure 1: Initiation of shoot from the callus of Protab (left) Variety using MS+1.0 mg/l NAA +0.1 mg/l BAP and Green Ball Variety using MS+1.5 mg/l NAA +0.5 mg/ BAP(right)

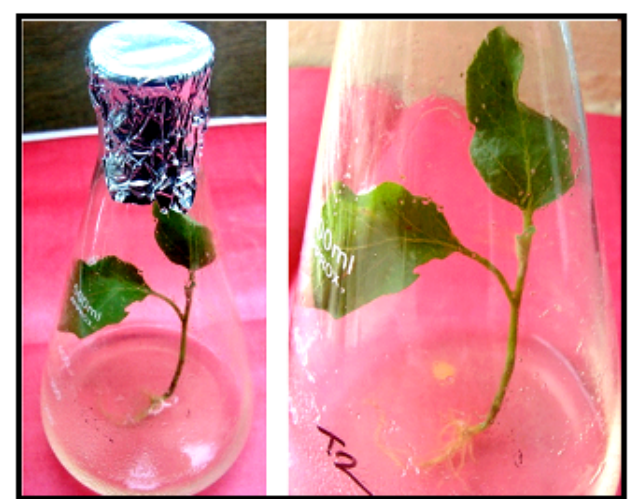

Fig. 2: Root initiation from regenerated shoot of Protab Variety in $1 / 2 \mathrm{MS}+2 \mathrm{mg} / \mathrm{l}$ IBA+0.4 mg/l BAP (left) and Green Ball Variety in $1 / 2 \mathrm{MS}+1 \mathrm{mg} / \mathrm{IBA}+0.3 \mathrm{mg} / \mathrm{BAP}$ (right)

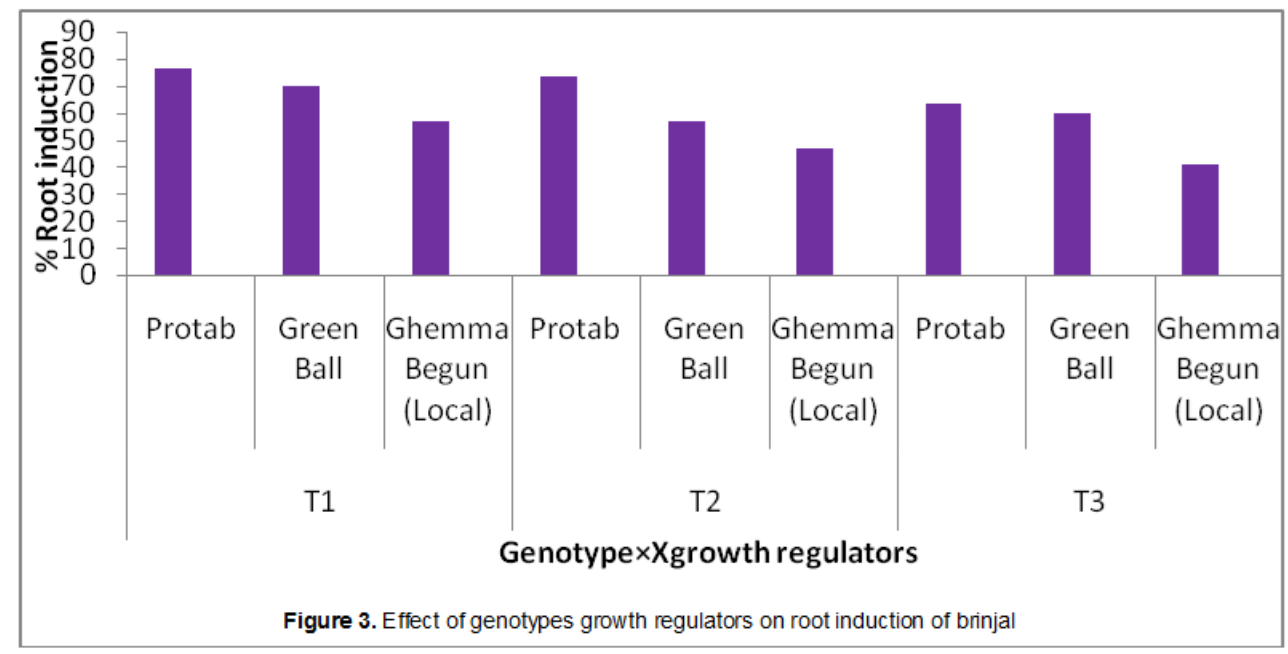




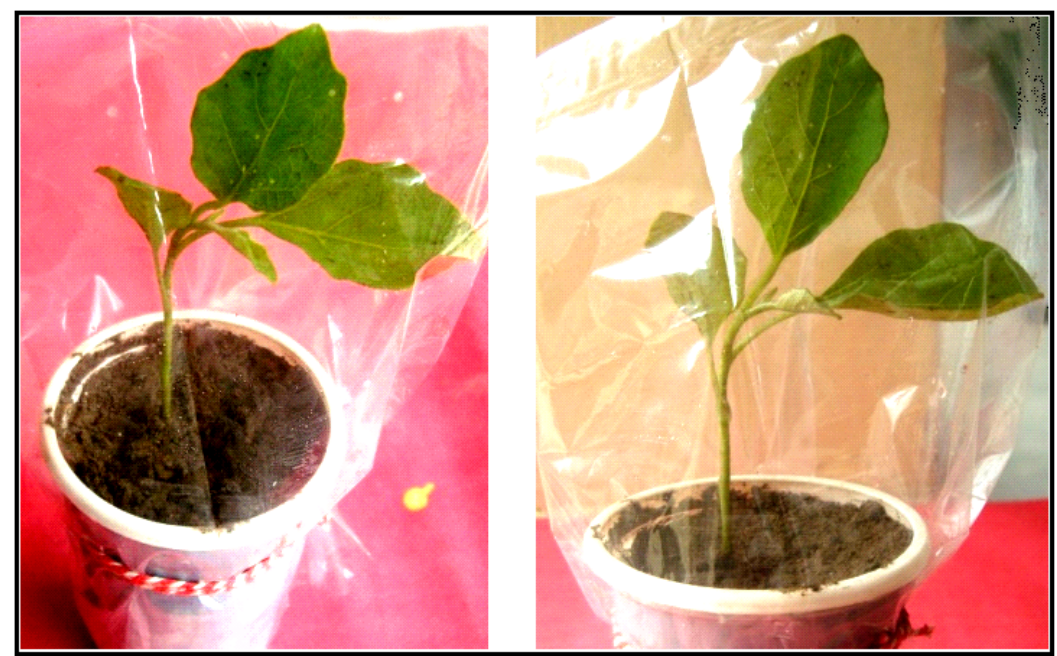

Figure 4. Hardening of regenerated plant of Protab (left) and Ghemma Begun (Local) (right) after transplantation into small plastic pot

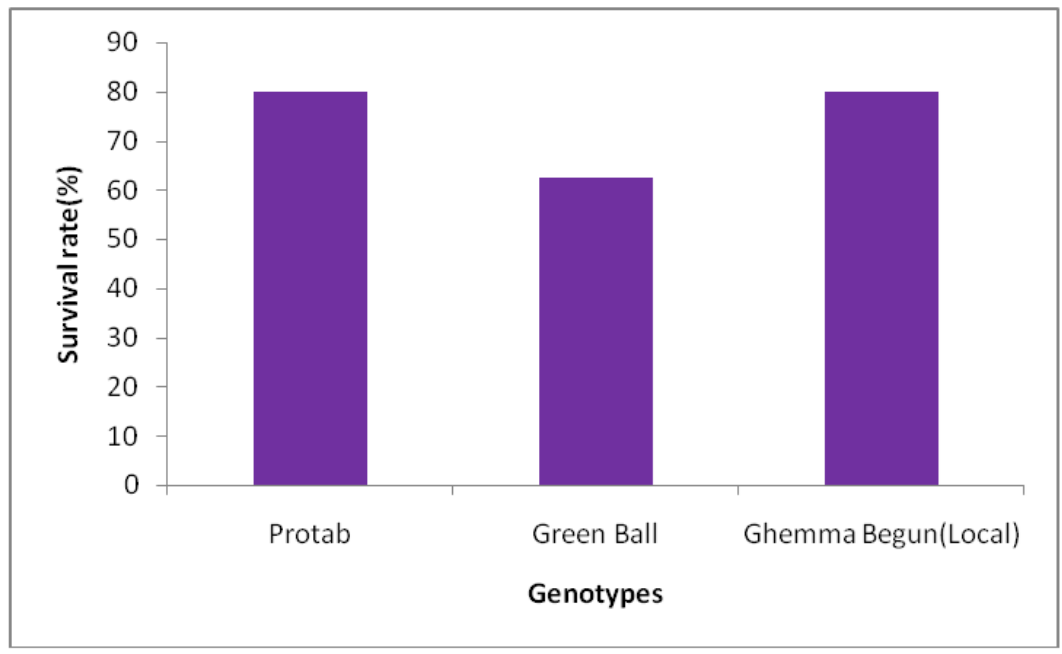

Figure 5. Effect of genotypes on survival rate of brinjal

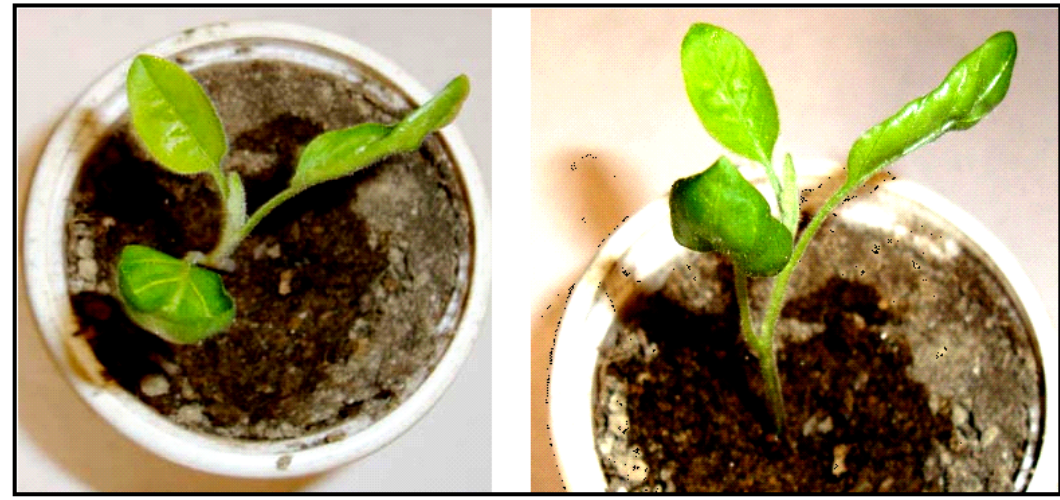

Figure 6. Survived plant after hardening of Protab (left) and Ghemma Begun (Local) (right) Variety derived from leaf explant 


\section{Growth regulator $x$ genotype interaction on root induction}

Results related to hormone $x$ genotype interaction for the characters of root regeneration such as number of shoots with root, percent root formation and days required to root initiation in different concentrations of MS, IBA and BAP showed significant variations. The results are presented in Table 6. Among the three genotypes, Protab showed best performance on number of shoots with root (7.667), best performance on percent root regeneration (76.67\%) in $\mathrm{T}_{1}(1 / 2 \mathrm{MS}+2 \mathrm{mg} / \mathrm{L} \mathrm{IBA}+0.4 \mathrm{mg} / \mathrm{L} \mathrm{BAP})$. In contrast, Ghemma Begun (Local) showed the lowest performance on number of shoots with root(4.067), lowest performance on percent root regeneration (40.67\%) with $1 / 2 \mathrm{MS}+0.5 \mathrm{mg} / \mathrm{L} \mathrm{IBA}+0.2 \mathrm{mg} / \mathrm{L} \mathrm{BAP}\left(\mathrm{T}_{3}\right)$.Days required for root initiation was minimum (6.000 days) on the interaction of $1 / 2 \mathrm{MS}+2 \mathrm{mg} / \mathrm{L} \mathrm{IBA}+0.4 \mathrm{mg} / \mathrm{L} \mathrm{BAP}$ ( $\mathrm{T}_{1}$ ) with Protab and maximum (9.333 days) on the interaction $1 / 2 \mathrm{MS}+0.5 \mathrm{mg} / \mathrm{L} \mathrm{IBA}+0.2 \mathrm{mg} / \mathrm{L} \mathrm{BAP}\left(\mathrm{T}_{3}\right)$.

From the above results, it may be concluded that $1 / 2 \mathrm{MS}+2 \mathrm{mg} / \mathrm{lBA}+0.4 \mathrm{mg} / \mathrm{l} \mathrm{BAP}\left(\mathrm{T}_{1}\right)$ with Protab showed the best performance on root regeneration. IBA is widely used for efficient root induction in Brinjal (Zayova et al., 2012). This result was in agreement with those obtained by Hossain et al. (2007), Prabavathi et al. (2007). Root initiation from regenerated shoot is shown in Fig. 2 and 3.

\section{Establishment of plantlet}

After sufficient development of root system, the small plantlets were taken out from culture vessels without any damage to roots and shoots .Medium adhered around the roots was removed by washing in running tap water to prevent microbial infection. The plantlets were then transplanted into plastic pots containing sterile soil, sand and cow dung in a 1:2:1 ratio. The pots were then covered with clear polyethylene bag to maintain high humidity conditions and kept in the growth chamber for proper hardening. Gradually the plantlets were adapted to soil and established. The survival rate of transferred regenerated plantlets after hardening was highest in Ghemma Begun (Local) (80\%) and lowest in Green ball (62.5\%).Similar result was found Ferdausi et al., 2009. Hardening of regenerated plant and survived plant after hardening from leaf explants are shown in Figure 4 and 5.

\section{CONCLUSION}

By considering the overall investigation and comparing the performance of three brinjal genotypes, it was found that Protab was the best cultivar in case of shoot regeneration and root induction. The findings from the present investigation of the effect of genotypes and growth regulators on shoot regeneration and root induction of brinjal (Solanummelongena.) could be efficiently utilized for the advanced biotechnological research, as for example gene transfer and crop improvement.

\section{REFERENCE}

1. BBS, 2011. Statistical Yearbook of Bangladesh. Bangladesh Bureau of Statistics.Ministry of planning, Government of the people's Repubic of Bangladesh. Dhaka, Bangladesh.

2. Bardhan SK, C Sharma and DK Srivastava, 2012. Invito plant regeneration studies in brinjal. Journal of Cell andTissue Research, 12: 3213-3218.

3. Bose TK and MG Som, 1986. Vegetable crops in India. Nayaprokah, Calcutta.

4. Das GP, S Ramaswamy and MA Bari, 2000. Integrated crop management practices for the control of the brinjal shoot and fruit borer in Bangladesh. DAE-DANIDA Strengthening Plant Protection Services (SPPS) Project. Department of Agriculture Extention, Khamarbari, Dhaka.

5. Ferdausi U, K Nath, BL Das and MS Alam, 2009. In vitro regeneration system in brinjal (Solanum melongena L.) for stress tolerant somaclone selection Journal of Agricultural University, 7: 253258.

6. Hossain MJ, M Rahman and MA Bari, 2007. Establishment of cell suspension culture and plantlet regeneration of brinjal (Solanum melongena L.). Journal of Plant Science, 2: 407-415.

7. Jayasree $T, V$ Paban, M Ramesh, AV Rao and KJM Reddy, 2001. Somatic embryogenesis from leaf cultures of potato. Plant Cell Tissue Organ Culture, 64: 13-17. 
8. Jorge PAR, LC Neyra, RM Osaki, E Almeida and N Bragagnolo, 1998. Efeito da berinjelasobreos lipids plasmáticos, a peroxidaçãolipídica e a reversão da disfunçãoendotelialnahipercolesteromia experimental. ArquivosBrasileiros de Cardiologia, 70: 87-91.

9. Magioli C and E Mansuri, 2005. Eggplant (Solanum melongenaL.): tissue culture, genetic transformation and use as an alternative model plant. Acta Botanica Brasilica, 19: 139-148.

10. Mir KA, AS Dhatt, JS Sandhu and AS Sidhu, 2011. Effect of genotype, explant and culture medium on organogenesis in brinjal. Indian Journal of Horticulture, 68: 332-335.

11. Prakash DP, BS Deepali, R Asokan, YL Ramachandra, DL Shetti, L Anand, VS Hanur, 2008. Effect of growth regulators on in vitro complete plant regeneration in brinjal. Indian Journal of Horticulture, 65: 371-376.

12. Rahman MD and DL Berquam, 2006. Plant cell and Tissue culture: The role of Haberlandt. Botanical Review, 35: 59-88.

13. Ray BP, L Hassan and KM Nasiruddin, 2011. In vitro regeneration of brinjal (Solanummelongena L.) Bangladesh Journal of Agricultural Research, 36: 397-406.

14. Sadilova E, FC Stintzing, R Carle, E Van and A Synder, 2006. Anthocyanins, colour and antioxidant properties of eggplant (Solanum melongena L.) and violet pepper (Capsicum anmium L.). Methods of Molecular Biology, 343: 439-447.

15. Shivraj G and S Rao, 2011. Rapid and efficient regeneration of eggplant (Solanum melongena L.) Indian Journal of Biotechnology, 10: 125-129.

16. Zayova ER, Vassilevska-Ivanova, B Kraptchev and D Stoeva, 2012. Indirect shoot organogenesis of eggplant (Solanum melongena L.) Journal of Central European Agriculture, 13: 446-457.

17. Zeven AC and MP Zhukovsky, 1975. Dictionary of cultivated plants and their centres of Diversity. Wageningen, Netherlands. 